\title{
The cross-talk between spirochetal lipoproteins and immunity
}

\section{Theodoros Kelesidis*}

Division of Infectious Diseases, Department of Medicine, David Geffen School of Medicine, University of California Los Angeles, Los Angeles, CA, USA

\section{Edited by:}

Amy Rasley, Lawrence Livermore

National Laboratory, USA

\section{Reviewed by:}

Vida A. Dennis, Alabama State

University, USA

Sukanya Narasimhan, Yale University

School of Medicine, USA

${ }^{*}$ Correspondence:

Theodoros Kelesidis, Division of Infectious Diseases, Department of Medicine, David Geffen School of Medicine, 37-121 Center for Health Sciences, University of California Los Angeles, 10833 LeConte Avenue, Los Angeles, CA 90095, USA

e-mail: tkelesidis@mednet.ucla.edu
Spirochetal diseases such as syphilis, Lyme disease, and leptospirosis are major threats to public health. However, the immunopathogenesis of these diseases has not been fully elucidated. Spirochetes interact with the host through various structural components such as lipopolysaccharides (LPS), surface lipoproteins, and glycolipids. Although spirochetal antigens such as LPS and glycolipids may contribute to the inflammatory response during spirochetal infections, spirochetes such as Treponema pallidum and Borrelia burgdorferi lack LPS. Lipoproteins are most abundant proteins that are expressed in all spirochetes and often determine how spirochetes interact with their environment. Lipoproteins are pro-inflammatory, may regulate responses from both innate and adaptive immunity and enable the spirochetes to adhere to the host or the tick midgut or to evade the immune system. However, most of the spirochetal lipoproteins have unknown function. Herein, the immunomodulatory effects of spirochetal lipoproteins are reviewed and are grouped into two main categories: effects related to immune evasion and effects related to immune activation. Understanding lipoprotein-induced immunomodulation will aid in elucidating innate immunopathogenesis processes and subsequent adaptive mechanisms potentially relevant to spirochetal disease vaccine development and to inflammatory events associated with spirochetal diseases.

Keywords: spirochetes, lipoproteins, immunity, Borrelia, treponemes, lipopeptides, immunomodulation

\section{INTRODUCTION}

Spirochetes are the cause of important human diseases such as syphilis, Lyme disease, and leptospirosis that are major threats to public health (1). However, the immunopathogenesis of these diseases has not been fully elucidated. Tissue inflammation is characteristic of spirochetal diseases such as dermatitis in syphilis and Lyme disease, interstitial nephritis in leptospirosis, and periodontitis caused by oral treponemes $(2,3)$. Spirochetes such as: Treponema pallidum (T. pallidum) and Borrelia burgdorferi (B. burgdorferi), the pathogens for syphilis and Lyme disease, respectively (1), may persist for prolonged periods despite the induced immune responses in the host (4-6). Several mechanisms may explain how spirochetes may evade host defenses such as intracellular sequestration of the spirochetes, the antigenic variation of the spirochetes, manipulation of host defenses to delay, and/or suppress the onset of effective immune responses and structural features of the outer membrane in spirochetes that contribute to immune evasion (7-11).

Spirochetes have unique membrane structure that interacts with the immune system (Figure 1) (2,3,12-18). Although spirochetal antigens such as lipopolysaccharides (LPS), the main proinflammatory component of Gram-negative bacteria (19), and glycolipids may contribute to the inflammatory response during spirochetal infections, spirochetes such as T. pallidum and B. burgdorferi express abundantly membrane lipoproteins and induce strong immune responses (20-24) despite lack of LPS (2, $3,17,18)$. Thus, lipid-lipid interactions between spirochetes and the lipid rafts in eukaryotic host cells either through glycolipids
$(3,25,26)$ or lipoproteins $(2,18,22,27-31)$ may occur and these lipid interactions may be an important process that contributes to the immunopathogenesis of spirochetal diseases $(3,25,26)$.

In bacteria, membrane lipoproteins are important virulence factors, pro-inflammatory agonists, enzymes, receptors, modular components of ATP binding cassette (ABC) transporters, and protective immune targets that regulate innate immunity $(2,3)$. In contrast to other bacteria that do not express lipoproteins so abundantly $(2,3,27)$, lipoproteins have an important role in the virulence of spirochetes since they are most abundant proteins that are expressed in all spirochetes $(2,3,18,22,27-31)$. The spirochetes express numerous lipoprotein genes $[T$. pallidum has $>20$ (24), B. burgdorferi has $>100$ lipoproteins (23), and approximately $8 \%$ of $B$. burgdorferi genes may encode lipoproteins $(21,23)$ and Leptospira spp. Have $>140$ lipoprotein genes (32)]. Examples of abundant lipoproteins in spirochetes include Tp 47 of T. pallidum, OspA of B. burgdorferi, LipL32 of Leptospira species, and Vmp proteins of Borrelia species (Table 1). Finally, spirochetal lipoproteins have more prominent pro-inflammatory effects compared to other bacterial lipoproteins and synthetic lipopeptides (28).

Surface-exposed lipoproteins often determine how spirochetes interact with their environment and immunity (Figure 1) (2, $3,18,22,27-31)$. Lipoproteins may be present in different cellular compartments $(2,70,84)$ and their distribution varies among spirochetes $(7,18,85-88)$ (Figure 1). The NH2-terminal lipopeptide region is the part of the lipoprotein that confers its immunologic activity since removal of this lipid component removed the immunoregulatory properties of these lipoproteins 


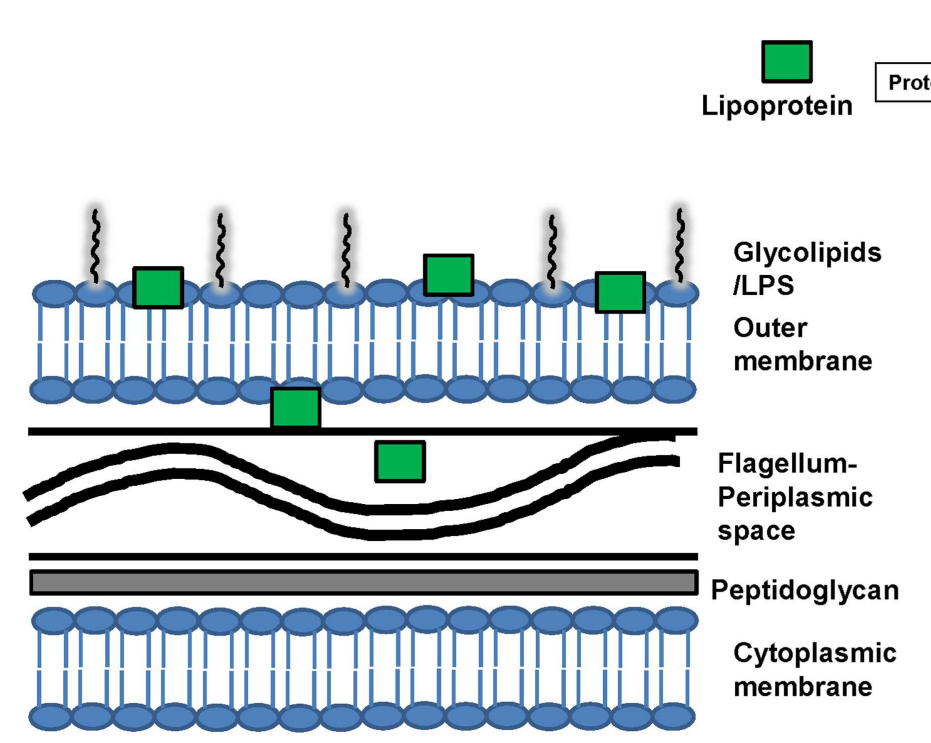

FIGURE 1 | Structure of spirochetal membrane and lipoproteins. Similarly to gram-positive bacteria, the spirochetal cytoplasmic membrane is associated with the cell wall that consists of peptidoglycan. Similarly to Gram-negative bacteria, spirochetes also have an outer membrane, which is not attached to the peptidoglycan layer. Spirochetes differ phylogenetically from Gram-negative bacteria and interact with the host through various structural components such as lipopolysaccharides (LPS), surface lipoproteins and glycolipids that are present mostly in the outer membrane. LPS has not been identified in Borrelia and Treponema. The periplasmic space contains the flagellum. The distribution of lipoproteins varies among spirochetes and they may be present in different cellular compartments: the outer membrane, the extracellular and the periplasmic spaces. For example the pro-inflammatory lipoproteins of T. pallidum are located below its cell surface and thus do not interact directly with the immune system of the host. It has been suggested that uptake and degradation of T. pallidum releases lipoproteins and allows their interaction with receptors on immune cells leading to immune cell activation. Computational programs can predict spirochetal protein lipidation but do not determine the location of lipoproteins in the cells. Recently, developed fluorescence activated cell sorting (FACS) and surface proteolysis methods can be used to screen for lipoprotein localization. Right upper corner: structure of spirochetal lipoproteins. The finding of a cysteine residue after a signal peptide $(+1)$ is suggestive evidence that a protein is lipidated. The spirochetal lipoproteins have a lipobox that is four amino acids in length and mediates $\mathrm{NH}$ 2-terminal lipidation on a conserved cysteine residue. Lipoproteins interact with the phospholipids of membranes via three hydrophobic N-terminal acyl moieties (often palmitate; C16) attached to a $\mathrm{N}$-terminal cysteine residue which may contribute to the localization of spirochetal lipoproteins. An analysis of the fatty acids of T. pallidum, B. burgdorferi, L. interrogans phospholipids and lipoproteins found that while fatty acids with different length side chains (C16 and C18) were found in phospholipids, palmitate (C16) predominated in the lipoproteins. The $\mathrm{N}$-terminal tripalmitoyl-S-glyceryl-cysteine (Pam3Cys) lipid moiety is the part of the lipoprotein that confers its immunologic activity. C, cysteine; LPS, lipopolysaccharides. while synthetic lipopeptides based on this lipid component could activate immune cells (Figure 1) (7-11, 18, 28, 89-93).

In vitro and in vivo studies suggest that spirochetal membrane lipoproteins and lipopeptides are pathogen-associated molecular patterns (PAMPs) that bind to pattern recognition receptors such as toll-like receptors (TLR1, 2). Thus, spirochetal lipoproteins are pro-inflammatory $(18,33,35-37,41,94)$ by activating endothelial cells $(36,77-80,95)$ and cells of innate immunity such as macrophages and dendritic cells (DCs) $(7-11,38,42-45,56,63,96$, 97). Spirochetal lipoproteins also enable the spirochetes to evade the immune system $(98,99)$ and adhere to the host $(100-104)$ or the tick midgut $(105,106)$ (Table 1). Finally, lipoproteins may be used as vaccine candidates for prevention of spirochetal infections $(2,3)$. The immunoregulatory effects of spirochetal lipoproteins have mostly been determined for major lipoproteins of T. pallidum (e.g., Tp47), B. burgdorferi (e.g., OspA, B), and Leptospira (e.g., LipL32) (Table 1). However, most spirochetal lipoproteins have not been well-studied and their interplay with immunity has recently been elucidated (Table S1 in Supplementary Material). Different methods have been used (Table 2) but observations in human models are often different from those obtained in vitro.
Lipoproteins are environmentally regulated and may be expressed selectively during spirochetal infection (37, 50, 112-116) (Table 1 in Supplementary Material). For example, the outersurface protein (Osp) A has a more important role in the pathogenesis of borrelial infection during the tick phase of B. burgdorferi and its expression is down regulated during the mammalian phase of B. burgdorferi infection (9). Thus, although OspA does not have a major role in regulation of host immunity in vivo, since it is not expressed during the later stages of borrelial infection, it has been used as a model to study in vitro the immunoregulatory effects of spirochetal lipoproteins (9). Herein, the immunomodulatory effects of spirochetal lipoproteins are reviewed and are grouped into two main categories: effects related to immune evasion and effects related to immune activation (Figure 2). Understanding these mechanisms will aid in elucidating the immunopathogenesis of chronic spirochetal diseases.

\section{THE ROLE OF SPIROCHETAL LIPOPROTEINS IN IMMUNE EVASION}

Spirochetes may use outer membrane lipoproteins to invade the host but host immunity may also target these lipoproteins. 
Table 1 | Immunoregulatory effects of major known spirochetal lipoproteins.

\begin{tabular}{|c|c|c|c|c|}
\hline Spirochetal lipoproteins & Endothelial cells & Neutrophils & Complement & $\begin{array}{l}\text { Antigen presenting cells: monocytes/ } \\
\text { macrophages/DCs }\end{array}$ \\
\hline $\begin{array}{l}\text { Treponema pallidum: mixture } \\
\text { of bacterial lipoproteins of } \\
\text { various MW [17 kDA (33), } \\
38 \mathrm{kDA}(34), 47 \mathrm{kDA}(35)] \text { and } \\
\text { related synthetic lipopeptides } \\
(22,30)\end{array}$ & $\begin{array}{l}\text { Activate directly host } \\
\text { vascular endothelium } \\
\text { which plays important } \\
\text { roles in lymphocyte } \\
\text { homing and hemostasis } \\
\text { (36) }\end{array}$ & NR & NR & $\begin{array}{l}\text { Stimulate macrophage and mDCs function: } \\
\text { costimulatory signals (DC-SIGN, CD14) (11, } \\
37,38) \text { and production of chemokines (CCR5) } \\
(39,40) \text {, cytokines such as TNF-a, IL-1 beta, } \\
\text { IL-6, and IL-12 }(18,33,35,41) \text { through TLRs } \\
\text { (42) and mostly TLR2 }(43) \text {, activated IL-12 p40 } \\
\text { promoter (42), NF-KB pathway }(37,38)\end{array}$ \\
\hline
\end{tabular}

outer-surface protein $A$ phagocytosis and oxidative burst of

human neutrophils

whereas OspA

induces the oxidative

burst in neutrophils

complement by

binding to $\mathrm{CFH}$ and chemokines (CXCL13) (51), pro-inflammatory

FHL-1 (47-49)

$(20,44-46)$
(47)

NR

endothelial cells

contributing to systemic

inflammation (77-80)
The calcium-binding cluster is crucial for the interaction between LipL32 and TLR2, which then triggers the signaling cascade of

inflammatory responses $(56,72,81)$
Lymphocytes

Up-regulate CCR5 expression on $\mathrm{CD} 4+\mathrm{T}$ cells $(39,40)$

Induce memory B cell immune responses (60), B cell proliferation and production of cytokines (61) and Th production of cytokines (IFN- $\gamma$ and IL-6) (62) and chemokines (CXCL13) (51). OspA may bind TLR 2 and 6 , activate $\mathrm{NF} \kappa \mathrm{B}$ and up-regulate costimulatory molecules as well as of MHC class II, leading to stronger $T$ cell activation (63-65); Possible molecular mimicry for T helper cells between OspA-1 and LFA-1 (66-68). OspA-1 may activate autoreactive $T$ cells against a

self-epitope and adaptive immune responses to OspA are implicated in the pathogenesis of antibioticrefractory Lyme arthritis $(68,69)$

Lipl32 has been used as immunogen for vaccine trials $(82,83)$ on the outer membrane of Leptospira and is expressed at high levels during infection (2, 70-76)

CFH, complement factor H; FHL-1, factor H-like protein 1; IL, interleukin; KDA, kilodalton; LipL32, 32-kDa lipoprotein of Leptospira; LFA-1, human lymphocyte function associated antigen 1; mDCs, myeloid dendritic cells; MW, molecular weight; NF-kB, NF-kappa B; NR, not reported; OspA, outer-surface protein A; OspB, outer-surface protein B; pDCs, plasmacytoid dendritic cells; TLR, toll-like receptor; Th, T helper; TNF-a, tumor necrosis factor. 
Table 2 | Methods used to determine in vitro and in vivo immunomodulatory properties of spirochetal lipopeptides/lipoproteins.

\section{Method}

Mutagenesis systems

Structural studies

Synthetic lipopeptides

Skin techniques: injection of the skin with synthetic lipopeptides

Identification of stereotypical responses to lipopeptides in vitro (synthetic lipopeptides) and in vivo (presence of similar histopathological abnormalities)

\section{Comments}

- The lack of mutagenesis systems for T. pallidum significantly impairs studies of their immunopathogenesis

- Mutagenesis systems for B. burgdorferi have recently been developed (107)

- T. pallidum cannot be cultured in the laboratory and structural studies have been used to elucidate the function of treponemal lipoproteins (108)

- The immunomodulatory properties of lipopeptides are conferred by the lipid moiety of their $\mathrm{N}$ termini and synthetic lipopeptides have been modeled after this structure to study native spirochetal lipoproteins (18, 33, 35-37, 41, 94)

- The synthetic lipopeptides have qualitatively similar immunostimulatory properties to those of native lipoproteins $(18,33,35-37,41,94)$

- Can be isolated in large amounts whereas large amounts of native lipoprotein cannot be isolated from spirochetes that cannot be cultured such as T. pallidum

- LPS contamination is a major problem when purifying bacterial lipoprotein while synthetic lipopeptides are synthesized under sterile conditions $(22,24,35)$

- Useful tools to study cellular responses induced by spirochetal lipopeptides within tissues

- Can be used instead of immunohistochemistry to characterize cellular infiltrates in target tissues of spirochetal disease $(40,109,110)$

- Often contribute to the understanding of specific immunomodulatory effects of spirochetal lipoproteins $(6,18,37,50,61,94,111)$

LPS, lipopolysaccharide.

However, all pathogenic spirochetes may cause persistent infections in humans by evading the host immune response through multiple mechanisms such as limiting the expression of membrane lipoproteins $(85)$ and their access to antibodies $(15,117)$ and antigenic variation of surface lipoproteins (Table 1) (2, 98, 118-124). Spirochetal lipoproteins may also interact with and inhibit components of innate immunity such as the complement $(10,43,56$, 57, 97, 125-130), neutrophils, and serum lipoproteins (131).

\section{SPIROCHETES USE ANTIGENIC VARIATION OF SURFACE LIPOPROTEINS TO EVADE IMMUNITY}

Antigenic variation in borrelias may result from recombination of variable large and small protein genes (122) and the diversity of Vmp lipoproteins allows these pathogens to evade the host immune response $(2,3)$. Studies in immunocompromised hosts have suggested that the host immune responses have a major role in producing spirochetal antigenic variants (120).

\section{SPIROCHETAL LIPOPROTEINS INHIBIT COMPLEMENT ACTIVATION}

Spirochetes may evade immune responses by inhibiting complement, a major innate immune system of the host $(132,133)$. Complement activation is caused by pathogen surface antigens such as LPS, antigen-antibody complexes, and binding of lectin to bacterial surfaces (134). Activation is regulated by host regulatory proteins, including factor $\mathrm{H}(\mathrm{FH})$ (134). Borrelia bind complement regulator $\mathrm{FH}$ and/or FH-like protein 1 (FHL-1) by directly interacting with Osp designated complement regulator-acquiring surface proteins (CRASPs) (135). Numerous surface spirochetal lipoproteins (outlined in Table $\mathbf{1}$; Table 1 in Supplementary Material; Figure 2) such as OspA, OspE, CspA may contribute to complement inhibition by binding to major complement regulatory proteins such as $\mathrm{FH}, \mathrm{FHL}-1 \mathrm{C} 4 \mathrm{~b}$-binding protein $(\mathrm{C} 4 \mathrm{bp})$ and human C1 esterase inhibitor (C1-Inh) (48, 99, 136-147). Thus, spirochetal lipoproteins contribute to immune evasion through complement inhibition.

\section{SPIROCHETAL LIPOPROTEINS MAY INHIBIT NEUTROPHIL FUNCTION}

Except for complement resistance, inhibition of neutrophil function is another mechanism that B. burgdorferi uses to evade the immune system. OspB inhibits the phagocytosis and oxidative burst of human neutrophils enabling $B$. burgdorferi to resist phagocytosis and oxidative burst in areas such as joint, skin, and the nervous system (47-49). Other spirochetal lipoproteins such as LIC11207 in Leptospira spp. may up-regulate the apoptosis of neutrophils (80). Thus, spirochetal lipoproteins may inhibit neutrophil function which may help the survival of the spirochetes.

\section{THE ROLE OF SPIROCHETAL LIPOPROTEINS IN IMMUNE ACTIVATION}

\section{SPIROCHETAL LIPOPROTEINS MAY ACTIVATE NEUTROPHILS}

Neutrophils are present in the joint fluid of Lyme arthritis patients (1), suggesting that they contribute to immune responses against B. burgdorferi. Although OspA and OspB are similarly regulated in the life cycle of $B$. burgdorferi, they have different functions. Contrary to OspB, OspA may activate human neutrophils (116) induce their oxidative burst (47) and induce neutrophil chemotaxis (148). OspA and OspC up-regulate complement receptor 


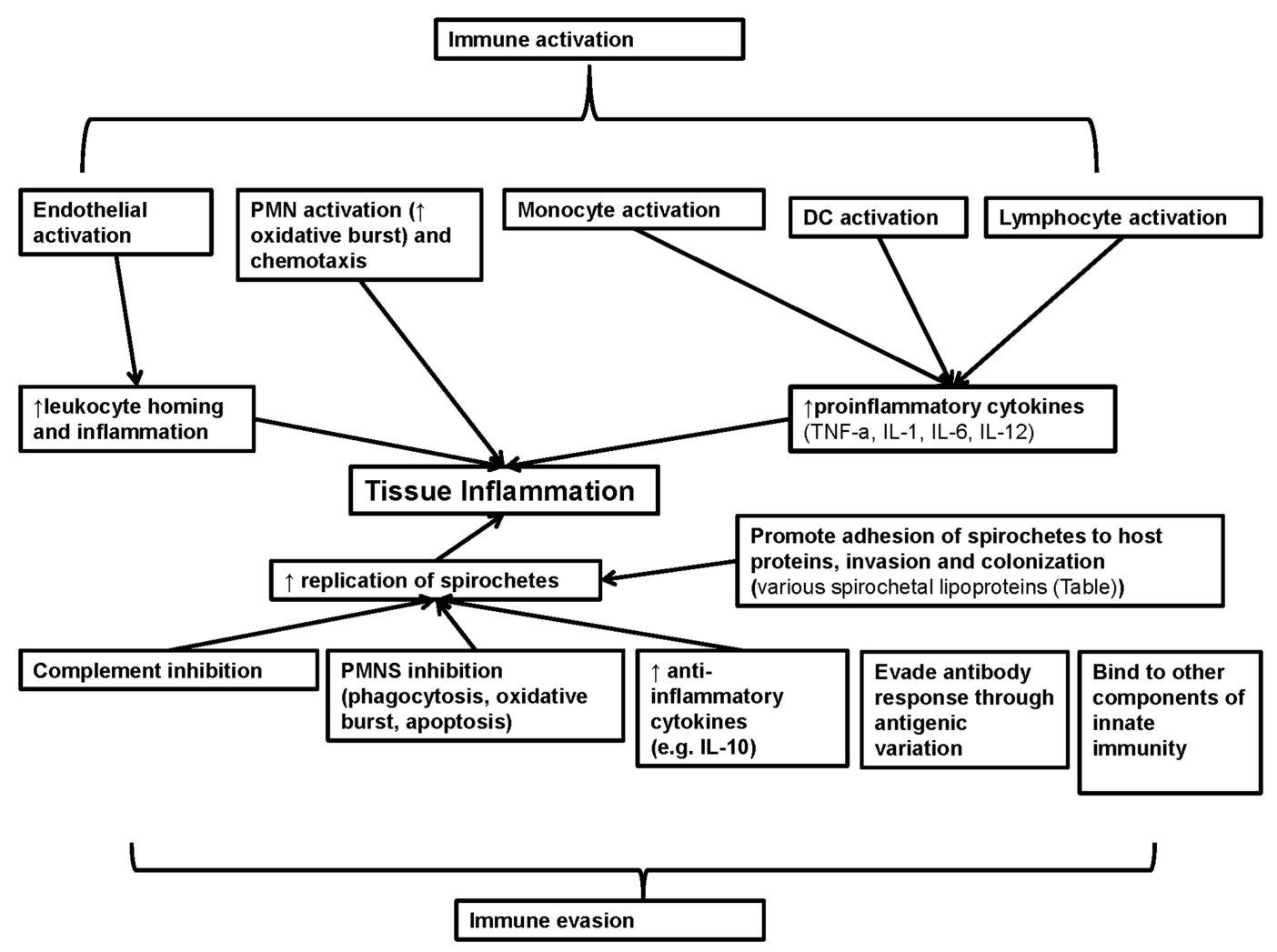

FIGURE 2 | Summary of the role of known spirochetal lipoproteins in regulation of immunity. Spirochetal lipoproteins have two different major effects on immunity: immune evasion and immune activation. These lipoproteins may contribute to immune evasion through inhibition of complement, neutrophils, production of anti-inflammatory cytokines, evasion of antibody responses through antigenic variation and binding to other components of innate immunity (e.g., apolipoproteins). In addition, spirochetal lipoproteins may directly promote spirochetal tissue invasion and colonization and in combination with immune evasion may lead to increased spirochetal replication and tissue inflammation. Spirochetal lipoproteins may also directly and indirectly activate endothelial, epithelial cells, and immune cells that contribute to innate immune responses (neutrophils, monocytes, macrophages, and DCs) or adaptive immune responses (lymphocytes such as B cells and CD4 T helper cells). Collectively, these effects lead to increase inflammation in target tissues (e.g., skin) or adaptive autoimmune responses (e.g., arthritis) that contribute to the clinical manifestations of spirochetal diseases. IL, interleukin; TNF-a, tumor necrosis factor $A$.
3 (CR3), an adhesion molecule expressed on neutrophils that is involved in the interactions of Borrelia species with neutrophils (149), and OspA and OspB may bind to CR3 in a C3bi independent manner (150). Thus, different spirochetal lipoproteins may inhibit neutrophils to evade immune responses but others may activate neutrophils contributing to tissue inflammation.

\section{SPIROCHETAL LIPOPROTEINS ACTIVATE MONOCYTES AND MACROPHAGES TO SECRETE CYTOKINES THROUGH CD14 AND TLR-DEPENDENT MECHANISMS}

Bacterial lipoproteins and LPS both have an active lipid moiety and induce similar cell responses in similar cell types (19). CD14 is a protein in the membrane of macrophages that binds LPS and also induces lipoprotein signaling in several cells $(38,97,151)$. Cellular membrane CD14 activates myeloid cells such as monocyte, macrophages, and polymorphonuclear white blood cells while soluble CD14 activates non-myeloid (endothelial, epithelial) cells (152). Spirochetal lipoproteins (such T. pallidum lipoproteins) bind to CD14 at the site that binds LPS and may activate monocytes and the NF-кB pathway through CD14 (38, 44,
97). In contrast to Gram-negative bacteria, LPS-binding protein (LBP) does not mediate interaction of spirochetal lipoproteins with CD14 (3, 38). However, TLR knockout and overexpression studies have confirmed that lipoproteins drive inflammation in syphilis and Lyme disease through TLR-dependent (TLR1, TLR2) responses $(10,43,56,57,97,125-130)$. Thus, during spirochetemia in Lyme disease and syphilis, spirochetal lipoproteins activate cells via TLR1 and TLR2 in contrast to Gram-negative sepsis where cellular activation occurs through TLR4 $(45,56,63)$. Integrin $\alpha 3 \beta 1$ may co-operate with TLR2/TLR1 in mediating proinflammatory responses in human macrophages stimulated with spirochetal lipopeptides such as BBB07 $(153,154)$. However, TLRindependent receptor responses are also important for spirochetal induced inflammation (125, 154-156). T. pallidum lipoproteins, the B. burgdorferi OspA lipoprotein and synthetic lipopetides may up-regulate macrophage production of pro-inflammatory cytokines such as TNF- $\alpha$, IL-1, IL-6, and IL-12 (18, 50). Many different cell types may produce IL-10 in response to stimulation by B. burgdorferi lipoproteins (52, 53, 62, 157, 158). On the other hand, endogenously produced and exogenous IL-10 
significantly reduced OspA lipoprotein-induced macrophage production of cytokines and chemokines (54, 62, 158-161), consistently with previous studies that have shown that IL-10 may down-regulate the TLR signaling pathway (159). Thus, spirochetal lipoproteins induce immune responses in antigen presenting cells such as monocytes and macrophages through TLR-dependent and -independent mechanisms.

\section{Spirochetal lipoproteins activate dendritic cells}

Except for monocytes and macrophages, spirochetal lipoproteins may also activate other antigen presenting cells such as DCs. DCs are a major link between innate and adaptive immunity, since after activation, they up-regulate costimulatory molecules such as CD54 that interact with $\mathrm{T}$ cell receptors such as $\mathrm{CD} 11 \mathrm{a} / \mathrm{CD} 18$ within lymph nodes $(162,163)$. Consistent with the hypothesis that lipoproteins are key pro-inflammatory mediators in spirochetal diseases, many studies have shown that treponemal lipoproteins and synthetic lipopeptides can up-regulate CD54 and contribute to DC activation $(18,33,35-37,41,94)$. Phagocytosis of intact spirochetes, activation of TLRs at phagosomes and bacterial cell death may result in the release of treponemal lipoproteins and may also contribute to immune cell activation (163). Also B. burgdorferi lipoproteins increase chemotaxis of circulating plasmacytoid dendritic cells (pDCs) into skin (11) but do not activate pDCs in vitro and in vivo $(58,59)$.

\section{SPIROCHETAL LIPOPROTEINS INDUCE INFLAMMATORY INFILTRATE INTO TARGET TISSUES AND ADAPTIVE IMMUNE RESPONSES IN VIVO THAT CONTRIBUTE TO CLINICAL MANIFESTATIONS OF SPIROCHETAL DISEASES}

Although lipoproteins may activate neutrophils, macrophages, endothelial cells in vitro, they may also induce inflammatory infiltrate into target tissues during spirochetal infection in vivo $(37,50,61,94,115,116,164)$. Lipoproteins may also contribute to the pathogenesis of the Jarisch-Herxheimer reaction, a transient immunological phenomenon that occurs during treatment of spirochetal infections $(165,166)$. Injection of synthetic lipopeptides into the skin can also be used to study the immunomodulatory effects of spirochetal lipoproteins in vivo (94). Cutaneous injection of spirochetal lipopeptides and spirochetal skin infections elicit similar cellular infiltrate supporting the hypothesis that spirochetal lipoproteins recruit diverse leukocytes from peripheral blood into target tissues (10). Lipoprotein-responsive cells (167), such as endothelium $(95,168)$, keratinocytes (169), and macrophages (170) induce chemotaxis of mixed cellular infiltrate that in combination with extravasating leukocytes further increase the tissue inflammatory response. Spirochetal lipoproteins activate in vivo antigen presenting cells (macrophages, DCs, CD4+ T cells) within the inflamed skin in spirochetal diseases $(39,40,58$, 59). Lipopeptides in combination with other antigens from spirochetes facilitate the transition from innate to prolonged adaptive immune responses that contribute to chronic manifestations of spirochetal diseases such as syphilis and Lyme disease (11). Consistent with these data from in vivo studies, in vitro studies have demonstrated that spirochetal lipoproteins may directly activate both B and T cells (Table 1). These lipoprotein-induced adaptive immune responses may trigger autoimmune and vaccine immune responses (Table 1). Thus, spirochetal lipoproteins induce initially innate immunity and then adaptive immunity through recruitment of spirochete-specific $\mathrm{T}$ cells and tissue inflammation that is associated with clinical manifestations of spirochetal disease such as Lyme arthritis $(37,50,94,115,116,164)$.

\section{CONCLUSION}

Lipoproteins are widely expressed by many pathogens and have pro-inflammatory effects (171-223). Thus, an understanding of how lipoproteins interact with the immune system will aid in the understanding of the pathogenesis of many infections including spirochetal infections. In addition, elucidating the molecular mechanisms of lipoprotein-induced immunomodulation (summarized in Figure 2) will lead to a greater understanding of the inflammatory processes, innate and adaptive immune responses associated with spirochetal diseases that may contribute to spirochetal disease vaccine development (163).

\section{SUPPLEMENTAY MATERIAL}

The Supplementary Material for this article can be found online at http://www.frontiersin.org/Journal/10.3389/fimmu.2014.00310/ abstract

\section{REFERENCES}

1. Steere AC. Lyme disease. N Engl J Med (2001) 345(2):115-25. doi:10.1056/ NEJM200107123450207

2. Haake DA. Spirochaetal lipoproteins and pathogenesis. Microbiology (2000) 146(Pt 7):1491-504.

3. Schroder NW, Eckert J, Stubs G, Schumann RR. Immune responses induced by spirochetal outer membrane lipoproteins and glycolipids. Immunobiology (2008) 213(3-4):329-40. doi:10.1016/j.imbio.2007.11.003

4. Steere AC, Coburn J, Glickstein L. The emergence of Lyme disease. J Clin Invest (2004) 113(8):1093-101. doi:10.1172/JCI21681

5. Hook EW III, Peeling RW. Syphilis control - a continuing challenge. $N$ Engl J Med (2004) 351(2):122-4. doi:10.1056/NEJMp048126

6. Duray PH. Histopathology of clinical phases of human Lyme disease. Rheum Dis Clin North Am (1989) 15(4):691-710.

7. Radolf JD. Role of outer membrane architecture in immune evasion by Treponema pallidum and Borrelia burgdorferi. Trends Microbiol (1994) 2(9):307-11. doi:10.1016/0966-842X(94)90446-4

8. Radolf JD, Desrosiers DC. Treponema pallidum, the stealth pathogen, changes, but how? Mol Microbiol (2009) 72(5):1081-6. doi:10.1111/j.1365-2958.2009. 06711.x

9. Radolf JD, Caimano MJ, Stevenson B, Hu LT. Of ticks, mice and men: understanding the dual-host lifestyle of Lyme disease spirochaetes. Nat Rev Microbiol (2012) 10(2):87-99. doi:10.1038/nrmicro2714

10. Salazar JC, Hazlett KR, Radolf JD. The immune response to infection with Treponema pallidum, the stealth pathogen. Microbes Infect (2002) 4(11):1133-40. doi:10.1016/S1286-4579(02)01638-6

11. Salazar JC, Pope CD, Moore MW, Pope J, Kiely TG, Radolf JD. Lipoproteindependent and -independent immune responses to spirochetal infection. Clin Diagn Lab Immunol (2005) 12(8):949-58. doi:10.1128/CDLI.12.8.949-958. 2005

12. Paster BJ, Dewhirst FE, Weisburg WG, Tordoff LA, Fraser GJ, Hespell RB, et al. Phylogenetic analysis of the spirochetes. J Bacteriol (1991) 173(19):6101-9.

13. Barbour AG, Hayes SF. Biology of Borrelia species. Microbiol Rev (1986) 50(4):381-400.

14. Takayama K, Rothenberg RJ, Barbour AG. Absence of lipopolysaccharide in the Lyme disease spirochete, Borrelia burgdorferi. Infect Immun (1987) 55(9):2311-3.

15. Cox DL, Chang P, McDowall AW, Radolf JD. The outer membrane, not a coat of host proteins, limits antigenicity of virulent Treponema pallidum. Infect Immun (1992) 60(3):1076-83 
16. Hossain H, Wellensiek HJ, Geyer R, Lochnit G. Structural analysis of glycolipids from Borrelia burgdorferi. Biochimie (2001) 83(7):683-92. doi:10.1016/S03009084(01)01296-2

17. Rietschel ET, Schletter J, Weidemann B, El-Samalouti V, Mattern T, Zahringer U, et al. Lipopolysaccharide and peptidoglycan: CD14-dependent bacterial inducers of inflammation. Microb Drug Resist (1998) 4(1):37-44. doi:10.1089/mdr. 1998.4.37

18. Radolf JD, Arndt LL, Akins DR, Curetty LL, Levi ME, Shen Y, et al. Treponema pallidum and Borrelia burgdorferi lipoproteins and synthetic lipopeptides activate monocytes/macrophages. J Immunol (1995) 154(6):2866-77.

19. Ulevitch RJ, Tobias PS. Recognition of Gram-negative bacteria and endotoxin by the innate immune system. Curr Opin Immunol (1999) 11(1):19-22. doi:10.1016/S0952-7915(99)80004-1

20. Brandt ME, Riley BS, Radolf JD, Norgard MV. Immunogenic integral membrane proteins of Borrelia burgdorferi are lipoproteins. Infect Immun (1990) 58(4):983-91.

21. Casjens S, Palmer N, van VR, Huang WM, Stevenson B, Rosa P, et al. A bacterial genome in flux: the twelve linear and nine circular extrachromosomal DNAs in an infectious isolate of the Lyme disease spirochete Borrelia burgdorferi. $\mathrm{Mol}$ Microbiol (2000) 35(3):490-516. doi:10.1046/j.1365-2958.2000.01698.x

22. Chamberlain NR, Brandt ME, Erwin AL, Radolf JD, Norgard MV. Major integral membrane protein immunogens of Treponema pallidum are proteolipids. Infect Immun (1989) 57(9):2872-7.

23. Fraser CM, Casjens S, Huang WM, Sutton GG, Clayton R, Lathigra R, et al. Genomic sequence of a Lyme disease spirochaete, Borrelia burgdorferi. Nature (1997) 390(6660):580-6. doi:10.1038/37551

24. Fraser CM, Norris SJ, Weinstock GM, White O, Sutton GG, Dodson R, et al. Complete genome sequence of Treponema pallidum, the syphilis spirochete. Science (1998) 281(5375):375-88. doi:10.1126/science.281.5375.375

25. LaRocca TJ, Crowley JT, Cusack BJ, Pathak P, Benach J, London E, et al. Cholesterol lipids of Borrelia burgdorferi form lipid rafts and are required for the bactericidal activity of a complement-independent antibody. Cell Host Microbe (2010) 8(4):331-42. doi:10.1016/j.chom.2010.09.001

26. Crowley JT, Toledo AM, LaRocca TJ, Coleman JL, London E, Benach JL. Lipid exchange between Borrelia burgdorferi and host cells. PLoS Pathog (2013) 9(1):e1003109. doi:10.1371/journal.ppat.1003109

27. Liang FT, Nelson FK, Fikrig E. DNA microarray assessment of putative Borrelia burgdorferi lipoprotein genes. Infect Immun (2002) 70(6):3300-3. doi:10.1128/IAI.70.6.3300-3303.2002

28. Weis JJ, Ma Y, Erdile LF. Biological activities of native and recombinant Borrelia burgdorferi outer surface protein A: dependence on lipid modification. Infect Immun (1994) 62(10):4632-6.

29. Braun V, Hantke K. Biochemistry of bacterial cell envelopes. Annu Rev Biochem (1974) 43(0):89-121. doi:10.1146/annurev.bi.43.070174.000513

30. Radolf JD, Chamberlain NR, Clausell A, Norgard MV. Identification and localization of integral membrane proteins of virulent Treponema pallidum subsp. pallidum by phase partitioning with the nonionic detergent triton X-114. Infect Immun (1988) 56(2):490-8.

31. Bricker TM, Boyer MJ, Keith J, Watson-McKown R, Wise KS. Association of lipids with integral membrane surface proteins of Mycoplasma hyorhinis. Infect Immun (1988) 56(2):295-301.

32. Setubal JC, Reis M, Matsunaga J, Haake DA. Lipoprotein computational prediction in spirochaetal genomes. Microbiology (2006) 152(Pt 1):113-21. doi:10.1099/mic.0.28317-0

33. Akins DR, Purcell BK, Mitra MM, Norgard MV, Radolf JD. Lipid modification of the 17-kilodalton membrane immunogen of Treponema pallidum determines macrophage activation as well as amphiphilicity. Infect Immun (1993) 61(4):1202-10.

34. Richarme G, Kohiyama M. Purification of the MglC/E membrane proteins of the binding protein-dependent galactose transport system of Salmonella typhimurium. FEBS Lett (1992) 304(2-3):167-9. doi:10.1016/0014-5793(92) 80611-J

35. DeOgny L, Pramanik BC, Arndt LL, Jones JD, Rush J, Slaughter CA, et al. Solidphase synthesis of biologically active lipopeptides as analogs for spirochetal lipoproteins. Pept Res (1994) 7(2):91-7.

36. Riley BS, Oppenheimer-Marks N, Hansen EJ, Radolf JD, Norgard MV. Virulent Treponema pallidum activates human vascular endothelial cells. J Infect Dis (1992) 165(3):484-93. doi:10.1093/infdis/165.3.484
37. Norgard MV, Arndt LL, Akins DR, Curetty LL, Harrich DA, Radolf JD. Activation of human monocytic cells by Treponema pallidum and Borrelia burgdorferi lipoproteins and synthetic lipopeptides proceeds via a pathway distinct from that of lipopolysaccharide but involves the transcriptional activator NF-kappa B. Infect Immun (1996) 64(9):3845-52.

38. Sellati TJ, Bouis DA, Kitchens RL, Darveau RP, Pugin J, Ulevitch RJ, et al. Treponema pallidum and Borrelia burgdorferi lipoproteins and synthetic lipopeptides activate monocytic cells via a CD14-dependent pathway distinct from that used by lipopolysaccharide. J Immunol (1998) 160(11):5455-64.

39. Sellati TJ, Wilkinson DA, Sheffield JS, Koup RA, Radolf JD, Norgard MV. Virulent Treponema pallidum, lipoprotein, and synthetic lipopeptides induce CCR5 on human monocytes and enhance their susceptibility to infection by human immunodeficiency virus type 1. J Infect Dis (2000) 181(1):283-93. doi: $10.1086 / 315209$

40. Sellati TJ, Waldrop SL, Salazar JC, Bergstresser PR, Picker LJ, Radolf JD. The cutaneous response in humans to Treponema pallidum lipoprotein analogues involves cellular elements of both innate and adaptive immunity. J Immunol (2001) 166(6):4131-40. doi:10.4049/jimmunol.166.6.4131

41. Radolf JD, Norgard MV, Brandt ME, Isaacs RD, Thompson PA, Beutler B. Lipoproteins of Borrelia burgdorferi and Treponema pallidum activate cachectin/tumor necrosis factor synthesis. Analysis using a CAT reporter construct. J Immunol (1991) 147(6):1968-74.

42. Brightbill HD, Libraty DH, Krutzik SR, Yang RB, Belisle JT, Bleharski JR, et al. Host defense mechanisms triggered by microbial lipoproteins through toll-like receptors. Science (1999) 285(5428):732-6. doi:10.1126/science.285.5428.732

43. Lien E, Sellati TJ, Yoshimura A, Flo TH, Rawadi G, Finberg RW, et al. Tolllike receptor 2 functions as a pattern recognition receptor for diverse bacterial products. J Biol Chem (1999) 274(47):33419-25. doi:10.1074/jbc.274.47.33419

44. Giambartolomei GH, Dennis VA, Lasater BL, Philipp MT. Induction of proand anti-inflammatory cytokines by Borrelia burgdorferi lipoproteins in monocytes is mediated by CD14. Infect Immun (1999) 67(1):140-7.

45. Hirschfeld M, Kirschning CJ, Schwandner R, Wesche H, Weis JH, Wooten RM, et al. Cutting edge: inflammatory signaling by Borrelia burgdorferi lipoproteins is mediated by toll-like receptor 2. J Immunol (1999) 163(5):2382-6.

46. Bergstrom S, Bundoc VG, Barbour AG. Molecular analysis of linear plasmidencoded major surface proteins, OspA and OspB, of the Lyme disease spirochaete Borrelia burgdorferi. Mol Microbiol (1989) 3(4):479-86. doi:10. 1111/j.1365-2958.1989.tb00194.x

47. Hartiala P, Hytonen J, Suhonen J, Lepparanta O, Tuominen-Gustafsson H, Viljanen MK. Borrelia burgdorferi inhibits human neutrophil functions. Microbes Infect (2008) 10(1):60-8. doi:10.1016/j.micinf.2007.10.004

48. van Burgel ND, Kraiczy P, Schuijt TJ, Zipfel PF, van Dam AP. Identification and functional characterisation of complement regulator acquiring surface protein-1 of serum resistant Borrelia garinii OspA serotype 4. BMC Microbiol (2010) 10:43. doi:10.1186/1471-2180-10-43

49. Sadziene A, Thomas DD, Barbour AG. Borrelia burgdorferi mutant lacking Osp: biological and immunological characterization. Infect Immun (1995) 63(4):1573-80.

50. Ma Y, Seiler KP, Tai KF, Yang L, Woods M, Weis JJ. Outer surface lipoproteins of Borrelia burgdorferi stimulate nitric oxide production by the cytokineinducible pathway. Infect Immun (1994) 62(9):3663-71.

51. Rupprecht TA, Kirschning CJ, Popp B, Kastenbauer S, Fingerle V, Pfister $\mathrm{HW}$, et al. Borrelia garinii induces CXCL13 production in human monocytes through toll-like receptor 2. Infect Immun (2007) 75(9):4351-6. doi:10.1128/ IAI.01642-06

52. Giambartolomei GH, Dennis VA, Philipp MT. Borrelia burgdorferi stimulates the production of interleukin-10 in peripheral blood mononuclear cells from uninfected humans and rhesus monkeys. Infect Immun (1998) 66(6):2691-7.

53. Giambartolomei GH, Dennis VA, Lasater BL, Murthy PK, Philipp MT. Autocrine and exocrine regulation of interleukin-10 production in THP-1 cells stimulated with Borrelia burgdorferi lipoproteins. Infect Immun (2002) 70(4):1881-8. doi:10.1128/IAI.70.4.1881-1888.2002

54. Brown JP, Zachary JF, Teuscher C, Weis JJ, Wooten RM. Dual role of interleukin10 in murine Lyme disease: regulation of arthritis severity and host defense. Infect Immun (1999) 67(10):5142-50.

55. Diterich I, Harter L, Hassler D, Wendel A, Hartung T. Modulation of cytokine release in ex vivo-stimulated blood from borreliosis patients. Infect Immun (2001) 69(2):687-94. doi:10.1128/IAI.69.2.687-694.2001 
56. Alexopoulou L, Thomas V, Schnare M, Lobet Y, Anguita J, Schoen RT, et al. Hyporesponsiveness to vaccination with Borrelia burgdorferi OspA in humans and in TLR1- and TLR2-deficient mice. Nat Med (2002) 8(8):878-84. doi:10.1038/nm732

57. Dennis VA, Dixit S, O'Brien SM, Alvarez X, Pahar B, Philipp MT. Live Borrelia burgdorferi spirochetes elicit inflammatory mediators from human monocytes via the toll-like receptor signaling pathway. Infect Immun (2009) 77(3):1238-45. doi:10.1128/IAI.01078-08

58. Jarrossay D, Napolitani G, Colonna M, Sallusto F, Lanzavecchia A. Specialization and complementarity in microbial molecule recognition by human myeloid and plasmacytoid dendritic cells. Eur J Immunol (2001) 31(11):3388-93. doi:10.1002/1521-4141(200111)31:11<3388::AIDIMMU3388>3.0.CO;2-Q

59. Kadowaki N, Ho S, Antonenko S, Malefyt RW, Kastelein RA, Bazan F, et al. Subsets of human dendritic cell precursors express different toll-like receptors and respond to different microbial antigens. J Exp Med (2001) 194(6):863-9. doi:10.1084/jem.194.6.863

60. Hogenesch H. Mechanisms of stimulation of the immune response by aluminum adjuvants. Vaccine (2002) 20(Suppl 3):S34-9. doi:10.1016/S0264$410 \mathrm{X}(02) 00169-\mathrm{X}$

61. Ma Y, Weis JJ. Borrelia burgdorferi outer surface lipoproteins OspA and OspB possess B-cell mitogenic and cytokine-stimulatory properties. Infect Immun (1993) 61(9):3843-53.

62. Ganapamo F, Dennis VA, Philipp MT. Early induction of gamma interferon and interleukin-10 production in draining lymph nodes from mice infected with Borrelia burgdorferi. Infect Immun (2000) 68(12):7162-5. doi:10.1128/IAI.68. 12.7162-7165.2000

63. Aliprantis AO, Yang RB, Mark MR, Suggett S, Devaux B, Radolf JD, et al. Cell activation and apoptosis by bacterial lipoproteins through toll-like receptor-2. Science (1999) 285(5428):736-9. doi:10.1126/science.285.5428.736

64. Bulut Y, Faure E, Thomas L, Equils O, Arditi M. Cooperation of toll-like receptor 2 and 6 for cellular activation by soluble tuberculosis factor and Borrelia burgdorferi outer surface protein A lipoprotein: role of toll-interacting protein and IL-1 receptor signaling molecules in Toll-like receptor 2 signaling. J Immunol (2001) 167(2):987-94. doi:10.4049/jimmunol.167.2.987

65. Hertz CJ, Kiertscher SM, Godowski PJ, Bouis DA, Norgard MV, Roth MD, et al. Microbial lipopeptides stimulate dendritic cell maturation via toll-like receptor 2. J Immunol (2001) 166(4):2444-50. doi:10.4049/jimmunol.166.4.2444

66. Gross DM, Forsthuber T, Tary-Lehmann M, Etling C, Ito K, Nagy ZA, et al. Identification of LFA- 1 as a candidate autoantigen in treatment-resistant Lyme arthritis. Science (1998) 281(5377):703-6. doi:10.1126/science.281.5377.703

67. Poland GA. Vaccines against Lyme disease: what happened and what lessons can we learn? Clin Infect Dis (2011) 52(Suppl 3):s253-8. doi:10.1093/cid/ciq116

68. Steere AC, Drouin EE, Glickstein LJ. Relationship between immunity to Borrelia burgdorferi outer-surface protein A (OspA) and Lyme arthritis. Clin Infect Dis (2011) 52(Suppl 3):s259-65. doi:10.1093/cid/ciq117

69. Drouin EE, Glickstein L, Kwok WW, Nepom GT, Steere AC. Human homologues of a Borrelia T cell epitope associated with antibiotic-refractory Lyme arthritis. Mol Immunol (2008) 45(1):180-9. doi:10.1016/j.molimm.2007.04. 017

70. Haake DA, Matsunaga J. Leptospira: a spirochaete with a hybrid outer membrane. Mol Microbiol (2010). doi:10.1111/j.1365-2958.2010.07262.x

71. Flannery B, Costa D, Carvalho FP, Guerreiro H, Matsunaga J, Da Silva ED, et al. Evaluation of recombinant Leptospira antigen-based enzyme-linked immunosorbent assays for the serodiagnosis of leptospirosis. J Clin Microbiol (2001) 39(9):3303-10. doi:10.1128/JCM.39.9.3303-3310.2001

72. Lo YY, Hsu SH, Ko YC, Hung CC, Chang MY, Hsu HH, et al. Essential calciumbinding cluster of Leptospira LipL32 protein for inflammatory responses through the toll-like receptor 2 pathway. J Biol Chem (2013) 288(17):12335-44. doi:10.1074/jbc.M112.418699

73. Pinne M, Haake DA. LipL32 is a subsurface lipoprotein of Leptospira interrogans: presentation of new data and reevaluation of previous studies. PLoS One (2013) 8(1):e51025. doi:10.1371/journal.pone.0051025

74. Malmstrom J, Beck M, Schmidt A, Lange V, Deutsch EW, Aebersold R. Proteome-wide cellular protein concentrations of the human pathogen Leptospira interrogans. Nature (2009) 460(7256):762-5. doi:10.1038/nature08184

75. Cullen PA, Xu X, Matsunaga J, Sanchez Y, Ko AI, Haake DA, et al. Surfaceome of Leptospira spp. Infect Immun (2005) 73(8):4853-63. doi:10.1128/IAI.73.8. 4853-4863.2005
76. Haake DA, Matsunaga J. Characterization of the leptospiral outer membrane and description of three novel leptospiral membrane proteins. Infect Immun (2002) 70(9):4936-45. doi:10.1128/IAI.70.9.4936-4945.2002

77. Sun Z, Bao L, Li D, Huang B, Wu B. Effect of Leptospira interrogans outer membrane proteins LipL32 on HUVEC. Microb Pathog (2010) 49(3):116-21. doi:10.1016/j.micpath.2010.05.006

78. Atzingen MV, Gomez RM, Schattner M, Pretre G, Goncales AP, de Morais ZM, et al. Lp95, a novel leptospiral protein that binds extracellular matrix components and activates e-selectin on endothelial cells. J Infect (2009) 59(4):264-76. doi:10.1016/j.jinf.2009.07.010

79. Gomez RM, Vieira ML, Schattner M, Malaver E, Watanabe MM, Barbosa AS, et al. Putative outer membrane proteins of Leptospira interrogans stimulate human umbilical vein endothelial cells (HUVECS) and express during infection. Microb Pathog (2008) 45(5-6):315-22. doi:10.1016/j. micpath.2008.08.004

80. Pretre G, Lapponi MJ, Atzingen MV, Schattner M, Nascimento AL, Gomez RM. Characterization of LIC11207, a novel leptospiral protein that is recognized by human convalescent sera and prevents apoptosis of polymorphonuclear leukocytes. Microb Pathog (2013) 56:21-8. doi:10.1016/j.micpath.2012.10.002

81. Hsu SH, Lo YY, Tung JY, Ko YC, Sun YJ, Hung CC, et al. Leptospiral outer membrane lipoprotein LipL32 binding on toll-like receptor 2 of renal cells as determined with an atomic force microscope. Biochemistry (2010) 49(26):5408-17. doi:10.1021/bi100058w

82. Grassmann AA, Felix SR, dos Santos CX, Amaral MG, Seixas Neto AC, Fagundes MQ, et al. Protection against lethal leptospirosis after vaccination with LipL32 coupled or coadministered with the B subunit of Escherichia coli heatlabile enterotoxin. Clin Vaccine Immunol (2012) 19(5):740-5. doi:10.1128/CVI. 05720- 11

83. Luo D, Xue F, Ojcius DM, Zhao J, Mao Y, Li L, et al. Protein typing of major outer membrane lipoproteins from Chinese pathogenic Leptospira spp. and characterization of their immunogenicity. Vaccine (2009) 28(1):243-55. doi:10.1016/j.vaccine.2009.09.089

84. Cullen PA, Haake DA, Adler B. Outer membrane proteins of pathogenic spirochetes. FEMS Microbiol Rev (2004) 28(3):291-318. doi:10.1016/j.femsre.2003. 10.004

85. Radolf JD, Norgard MV, Schulz WW. Outer membrane ultrastructure explains the limited antigenicity of virulent Treponema pallidum. Proc Natl Acad Sci U S A (1989) 86(6):2051-5. doi:10.1073/pnas.86.6.2051

86. Jones JD, Bourell KW, Norgard MV, Radolf JD. Membrane topology of Borrelia burgdorferi and Treponema pallidum lipoproteins. Infect Immun (1995) 63(7):2424-34.

87. Sellati TJ, Bouis DA, Caimano MJ, Feulner JA, Ayers C, Lien E, et al. Activation of human monocytic cells by Borrelia burgdorferi and Treponema pallidum is facilitated by CD14 and correlates with surface exposure of spirochetal lipoproteins. J Immunol (1999) 163(4):2049-56.

88. Underhill DM, Ozinsky A, Hajjar AM, Stevens A, Wilson CB, Bassetti M, et al. The toll-like receptor 2 is recruited to macrophage phagosomes and discriminates between pathogens. Nature (1999) 401(6755):811-5. doi:10.1038/44605

89. Biesert L, Scheuer W, Bessler WG. Interaction of mitogenic bacterial lipoprotein and a synthetic analogue with mouse lymphocytes. Isolation and characterization of binding proteins. Eur J Biochem (1987) 162(3):651-7. doi:10.1111/j. 1432-1033.1987.tb10687.x

90. Hauschildt S, Hoffmann P, Beuscher HU, Dufhues G, Heinrich P, Wiesmuller $\mathrm{KH}$, et al. Activation of bone marrow-derived mouse macrophages by bacterial lipopeptide: cytokine production, phagocytosis and Ia expression. Eur J Immunol (1990) 20(1):63-8. doi:10.1002/eji.1830200110

91. Bessler WG, Ottenbreit BP. Studies on the mitogenic principle of the lipoprotein from the outer membrane of Escherichia coli. Biochem Biophys Res Commun (1976) 76(2):239-46. doi:10.1016/0006-291X(77)90717-3

92. Bessler WG, Cox M, Lex A, Suhr B, Wiesmuller KH, Jung G. Synthetic lipopeptide analogs of bacterial lipoprotein are potent polyclonal activators for murine B lymphocytes. J Immunol (1985) 135(3):1900-5.

93. Hoffmann P, Heinle S, Schade UF, Loppnow H, Ulmer AJ, Flad HD, et al. Stimulation of human and murine adherent cells by bacterial lipoprotein and synthetic lipopeptide analogues. Immunobiology (1988) 177(2):158-70. doi:10.1016/S0171-2985(88)80036-6

94. Norgard MV, Riley BS, Richardson JA, Radolf JD. Dermal inflammation elicited by synthetic analogs of Treponema pallidum and Borrelia burgdorferi lipoproteins. Infect Immun (1995) 63(4):1507-15. 
95. Sellati TJ, Abrescia LD, Radolf JD, Furie MB. Outer surface lipoproteins of Borrelia burgdorferi activate vascular endothelium in vitro. Infect Immun (1996) 64(8):3180-7.

96. Takeuchi O, Sato S, Horiuchi T, Hoshino K, Takeda K, Dong Z, et al. Cutting edge: role of toll-like receptor 1 in mediating immune response to microbial lipoproteins. J Immunol (2002) 169(1):10-4. doi:10.4049/jimmunol.169.1.10

97. Wooten RM, Morrison TB, Weis JH, Wright SD, Thieringer R, Weis JJ. The role of CD14 in signaling mediated by outer membrane lipoproteins of Borrelia burgdorferi. J Immunol (1998) 160(11):5485-92.

98. Zhang JR, Hardham JM, Barbour AG, Norris SJ. Antigenic variation in Lyme disease borreliae by promiscuous recombination of VMP-like sequence cassettes. Cell (1997) 89(2):275-85. doi:10.1016/S0092-8674(00)80206-8

99. Hellwage J, Meri T, Heikkila T, Alitalo A, Panelius J, Lahdenne P, et al. The complement regulator factor $\mathrm{H}$ binds to the surface protein OspE of Borrelia burgdorferi. J Biol Chem (2001) 276(11):8427-35. doi:10.1074/jbc. M007994200

100. Guo BP, Brown EL, Dorward DW, Rosenberg LC, Hook M. Decorin-binding adhesins from Borrelia burgdorferi. Mol Microbiol (1998) 30(4):711-23. doi:10. 1046/j.1365-2958.1998.01103.x

101. Fikrig E, Feng W, Barthold SW, Telford SR III, Flavell RA. Arthropod- and hostspecific Borrelia burgdorferi bbk32 expression and the inhibition of spirochete transmission. J Immunol (2000) 164(10):5344-51. doi:10.4049/jimmunol.164. 10.5344

102. Probert WS, Johnson BJ. Identification of a $47 \mathrm{kDa}$ fibronectin-binding protein expressed by Borrelia burgdorferi isolate B31. Mol Microbiol (1998) 30(5):1003-15. doi:10.1046/j.1365-2958.1998.01127.x

103. Hauk P, Macedo F, Romero EC, Vasconcellos SA, de Morais ZM, Barbosa AS, et al. In LipL32, the major leptospiral lipoprotein, the $\mathrm{C}$ terminus is the primary immunogenic domain and mediates interaction with collagen IV and plasma fibronectin. Infect Immun (2008) 76(6):2642-50. doi:10.1128/IAI. 01639-07

104. Choy HA, Kelley MM, Chen TL, Moller AK, Matsunaga J, Haake DA. Physiological osmotic induction of Leptospira interrogans adhesion: LigA and LigB bind extracellular matrix proteins and fibrinogen. Infect Immun (2007) 75(5):2441-50. doi:10.1128/IAI.01635-06

105. Pal U, de Silva AM, Montgomery RR, Fish D, Anguita J, Anderson JF, et al. Attachment of Borrelia burgdorferi within Ixodes scapularis mediated by outer surface protein A. J Clin Invest (2000) 106(4):561-9. doi:10.1172/JCI9427

106. Pal U, Montgomery RR, Lusitani D, Voet P, Weynants V, Malawista SE, et al. Inhibition of Borrelia burgdorferi-tick interactions in vivo by outer surface protein A antibody. J Immunol (2001) 166(12):7398-403. doi:10.4049/jimmunol. 166.12.7398

107. Stewart PE, Hoff J, Fischer E, Krum JG, Rosa PA. Genome-wide transposon mutagenesis of Borrelia burgdorferi for identification of phenotypic mutants. Appl Environ Microbiol (2004) 70(10):5973-9. doi:10.1128/AEM.70.10.59735979.2004

108. Deka RK, Brautigam CA, Biddy BA, Liu WZ, Norgard MV. Evidence for an ABC-type riboflavin transporter system in pathogenic spirochetes. MBio (2013) 4(1):e615-612. doi:10.1128/mBio.00615-12

109. Salazar JC, Pope CD, Sellati TJ, Feder HM Jr, Kiely TG, Dardick KR, et al. Coevolution of markers of innate and adaptive immunity in skin and peripheral blood of patients with erythema migrans. J Immunol (2003) 171(5):2660-70. doi:10.4049/jimmunol.171.9.4934-a

110. Erbelding E. 2001 Syphilis rates show increase: does this portend a new wave of HIV infection? Hopkins HIV Rep (2003) 15(1):15.

111. Krutzik SR, Ochoa MT, Sieling PA, Uematsu S, Ng YW, Legaspi A, et al. Activation and regulation of toll-like receptors 2 and 1 in human leprosy. Nat Med (2003) 9(5):525-32. doi:10.1038/nm864

112. Schwan TG, Piesman J, Golde WT, Dolan MC, Rosa PA. Induction of an outer surface protein on Borrelia burgdorferi during tick feeding. Proc Natl Acad Sci U S A (1995) 92(7):2909-13. doi:10.1073/pnas.92.7.2909

113. Lengl-Janssen B, Strauss AF, Steere AC, Kamradt T. The T helper cell response in Lyme arthritis: differential recognition of Borrelia burgdorferi outer surface protein A in patients with treatment-resistant or treatment-responsive Lyme arthritis. J Exp Med (1994) 180(6):2069-78. doi:10.1084/jem.180.6.2069

114. de Silva AM, Fikrig E. Arthropod- and host-specific gene expression by Borrelia burgdorferi. J Clin Invest (1997) 99(3):377-9. doi:10.1172/JCI119169

115. Wooten RM, Modur VR, McIntyre TM, Weis JJ. Borrelia burgdorferi outer membrane protein A induces nuclear translocation of nuclear factor-kappa $\mathrm{B}$ and inflammatory activation in human endothelial cells. J Immunol (1996) 157(10):4584-90.

116. Morrison TB, Weis JH, Weis JJ. Borrelia burgdorferi outer surface protein A (OspA) activates and primes human neutrophils. J Immunol (1997) 158(10):4838-45.

117. Bunikis J, Barbour AG. Access of antibody or trypsin to an integral outer membrane protein (P66) of Borrelia burgdorferi is hindered by Osp lipoproteins. Infect Immun (1999) 67(6):2874-83.

118. Hinnebusch BJ, Barbour AG, Restrepo BI, Schwan TG. Population structure of the relapsing fever spirochete Borrelia hermsii as indicated by polymorphism of two multigene families that encode immunogenic outer surface lipoproteins. Infect Immun (1998) 66(2):432-40.

119. Zhang JR, Norris SJ. Genetic variation of the Borrelia burgdorferi gene vlsE involves cassette-specific, segmental gene conversion. Infect Immun (1998) 66(8):3698-704.

120. Zhang JR, Norris SJ. Kinetics and in vivo induction of genetic variation of vlsE in Borrelia burgdorferi. Infect Immun (1998) 66(8):3689-97.

121. Rogovskyy AS, Bankhead T. Variable VlsE is critical for host reinfection by the Lyme disease spirochete. PLoS One (2013) 8(4):e61226. doi:10.1371/journal. pone.0061226

122. Vidal V, Cutler S, Scragg IG, Wright DJ, Kwiatkowski D. Characterisation of silent and active genes for a variable large protein of Borrelia recurrentis. BMC Infect Dis (2002) 2:25. doi:10.1186/1471-2334-2-25

123. Schwan TG, Hinnebusch BJ. Bloodstream- versus tick-associated variants of a relapsing fever bacterium. Science (1998) 280(5371):1938-40. doi:10.1126/ science. 280.5371 .1938

124. Carter CJ, Bergstrom S, Norris SJ, Barbour AG. A family of surface-exposed proteins of 20 kilodaltons in the genus Borrelia. Infect Immun (1994) 62(7): 2792-9.

125. Bolz DD, Sundsbak RS, Ma Y, Akira S, Kirschning CJ, Zachary JF, et al. MyD88 plays a unique role in host defense but not arthritis development in Lyme disease. J Immunol (2004) 173(3):2003-10. doi:10.4049/jimmunol.173.3.2003

126. Benhnia MR, Wroblewski D, Akhtar MN, Patel RA, Lavezzi W, Gangloff SC, et al. Signaling through CD14 attenuates the inflammatory response to Borrelia burgdorferi, the agent of Lyme disease. J Immunol (2005) 174(3):1539-48. doi:10.4049/jimmunol.174.3.1539

127. Wang G, Ma Y, Buyuk A, McClain S, Weis JJ, Schwartz I. Impaired host defense to infection and toll-like receptor 2-independent killing of Borrelia burgdorferi clinical isolates in TLR2-deficient C3H/HeJ mice. FEMS Microbiol Lett (2004) 231(2):219-25. doi:10.1016/S0378-1097(03)00960-1

128. Wooten RM, Ma Y, Yoder RA, Brown JP, Weis JH, Zachary JF, et al. Toll-like receptor 2 is required for innate, but not acquired, host defense to Borrelia burgdorferi. J Immunol (2002) 168(1):348-55. doi:10.4049/jimmunol.168. 1.348

129. Wooten RM, Weis JJ. Host-pathogen interactions promoting inflammatory Lyme arthritis: use of mouse models for dissection of disease processes. Curr Opin Microbiol (2001) 4(3):274-9. doi:10.1016/S1369-5274(00)00202-2

130. Schroder NW, Diterich I, Zinke A, Eckert J, Draing C, von Baehr V, et al. Heterozygous Arg753Gln polymorphism of human TLR-2 impairs immune activation by Borrelia burgdorferi and protects from late stage Lyme disease. J Immunol (2005) 175(4):2534-40. doi:10.4049/jimmunol.175.4.2534

131. Bas S, James RW, Gabay C. Serum lipoproteins attenuate macrophage activation and toll-like receptor stimulation by bacterial lipoproteins. BMC Immunol (2010) 11:46. doi:10.1186/1471-2172-11-46

132. Alitalo A, Meri T, Comstedt P, Jeffery L, Tornberg J, Strandin T, et al. Expression of complement factor $\mathrm{H}$ binding immunoevasion proteins in Borrelia garinii isolated from patients with neuroborreliosis. Eur J Immunol (2005) 35(10):3043-53. doi:10.1002/eji.200526354

133. Alitalo A, Meri T, Ramo L, Jokiranta TS, Heikkila T, Seppala IJ, et al. Complement evasion by Borrelia burgdorferi: serum-resistant strains promote $\mathrm{C} 3 \mathrm{~b}$ inactivation. Infect Immun (2001) 69(6):3685-91. doi:10.1128/IAI.69.6.36853691.2001

134. Skerka C, Zipfel PF. Complement factor $\mathrm{H}$ related proteins in immune diseases. Vaccine (2008) 26(Suppl 8):I9-14. doi:10.1016/j.vaccine.2008.11.021

135. Kraiczy P, Skerka C, Brade V, Zipfel PF. Further characterization of complement regulator-acquiring surface proteins of Borrelia burgdorferi. Infect Immun (2001) 69(12):7800-9. doi:10.1128/IAI.69.12.7800-7809.2001

136. Bhattacharjee A, Oeemig JS, Kolodziejczyk R, Meri T, Kajander T, Lehtinen $\mathrm{MJ}$, et al. Structural basis for complement evasion by Lyme disease pathogen 
Borrelia burgdorferi. J Biol Chem (2013) 288(26):18685-95. doi:10.1074/jbc. M113.459040

137. Stevenson B, El-Hage N, Hines MA, Miller JC, Babb K. Differential binding of host complement inhibitor factor $\mathrm{H}$ by Borrelia burgdorferi Erp surface proteins: a possible mechanism underlying the expansive host range of Lyme disease spirochetes. Infect Immun (2002) 70(2):491-7. doi:10.1128/IAI.70.2. 491-497.2002

138. Matsunaga J, Schlax PJ, Haake DA. Role for cis-acting RNA sequences in the temperature-dependent expression of the multiadhesive lig proteins in Leptospira interrogans. J Bacteriol (2013) 195(22):5092-101. doi:10.1128/JB. 00663-13

139. Nowling JM, Philipp MT. Killing of Borrelia burgdorferi by antibody elicited by OspA vaccine is inefficient in the absence of complement. Infect Immun (1999) 67(1):443-5.

140. Kenedy MR, Akins DR. The OspE-related proteins inhibit complement deposition and enhance serum resistance of Borrelia burgdorferi, the lyme disease spirochete. Infect Immun (2011) 79(4):1451-7. doi:10.1128/IAI.01274-10

141. Kenedy MR, Vuppala SR, Siegel C, Kraiczy P, Akins DR. CspA-mediated binding of human factor $\mathrm{H}$ inhibits complement deposition and confers serum resistance in Borrelia burgdorferi. Infect Immun (2009) 77(7):2773-82. doi:10.1128/IAI.00318-09

142. Hartmann K, Corvey C, Skerka C, Kirschfink M, Karas M, Brade V, et al. Functional characterization of BbCRASP-2, a distinct outer membrane protein of Borrelia burgdorferi that binds host complement regulators factor $\mathrm{H}$ and FHL1. Mol Microbiol (2006) 61(5):1220-36. doi:10.1111/j.1365-2958.2006.05318.x

143. Panelius J, Meri T, Seppala I, Eholuoto M, Alitalo A, Meri S. Outer surface protein $\mathrm{E}$ antibody response and its effect on complement factor $\mathrm{H}$ binding to OspE in Lyme borreliosis. Microbes Infect (2008) 10(2):135-42. doi:10.1016/j.micinf.2007.10.016

144. Kraiczy P, Hartmann K, Hellwage J, Skerka C, Kirschfink M, Brade V, et al. Immunological characterization of the complement regulator factor $\mathrm{H}$ binding CRASP and Erp proteins of Borrelia burgdorferi. Int J Med Microbiol (2004) 293(Suppl 37):152-7. doi:10.1016/S1433-1128(04)80029-9

145. Brooks CS, Vuppala SR, Jett AM, Alitalo A, Meri S, Akins DR. Complement regulator-acquiring surface protein 1 imparts resistance to human serum in Borrelia burgdorferi. J Immunol (2005) 175(5):3299-308. doi:10.4049/ jimmunol.175.5.3299

146. Coleman AS, Yang X, Kumar M, Zhang X, Promnares K, Shroder D, et al. Borrelia burgdorferi complement regulator-acquiring surface protein 2 does not contribute to complement resistance or host infectivity. PLoS One (2008) 3(8):3010e. doi:10.1371/journal.pone.0003010

147. Bykowski T, Woodman ME, Cooley AE, Brissette CA, Wallich R, Brade V, et al. Borrelia burgdorferi complement regulator-acquiring surface proteins (BbCRASPs): expression patterns during the mammal-tick infection cycle. Int J Med Microbiol (2008) 298(Suppl 1):249-56. doi:10.1016/j.ijmm.2007.10.002

148. Benach JL, Coleman JL, Garcia-Monco JC, Deponte PC. Biological activity of Borrelia burgdorferi antigens. Ann N Y Acad Sci (1988) 539:115-25. doi:10.1111/j.1749-6632.1988.tb31845.x

149. Cinco M, Panfili E, Presani G, Perticarari S. Interaction with Borrelia burgdorferi causes increased expression of the CR3 integrin and increased binding affinity to fibronectin via CR3. J Mol Microbiol Biotechnol (2000) 2(4):575-9.

150. Garcia RC, Murgia R, Cinco M. Complement receptor 3 binds the Borrelia burgdorferi outer surface proteins OspA and OspB in an iC3b-independent manner. Infect Immun (2005) 73(9):6138-42. doi:10.1128/IAI.73.9.6138-6142. 2005

151. Wright SD, Ramos RA, Tobias PS, Ulevitch RJ, Mathison JC. CD14, a receptor for complexes of lipopolysaccharide (LPS) and LPS binding protein. Science (1990) 249(4975):1431-3. doi:10.1126/science.1698311

152. Ranoa DR, Kelley SL, Tapping RI. Human lipopolysaccharide-binding protein (LBP) and CD14 independently deliver triacylated lipoproteins to tolllike receptor 1 (TLR1) and TLR2 and enhance formation of the ternary signaling complex. J Biol Chem (2013) 288(14):9729-41. doi:10.1074/jbc.M113. 453266

153. Marre ML, Petnicki-Ocwieja T, DeFrancesco AS, Darcy CT, Hu LT. Human integrin alpha(3)beta(1) regulates TLR2 recognition of lipopeptides from endosomal compartments. PLoS One (2010) 5(9):e12871. doi:10.1371/journal.pone. 0012871

154. Behera AK, Durand E, Cugini C, Antonara S, Bourassa L, Hildebrand E, et al. Borrelia burgdorferi BBB07 interaction with integrin alpha3betal stimulates production of pro-inflammatory mediators in primary human chondrocytes. Cell Microbiol (2008) 10(2):320-31. doi:10.1111/j.1462-5822.2007.01043.x

155. Coburn J, Cugini C. Targeted mutation of the outer membrane protein P66 disrupts attachment of the Lyme disease agent, Borrelia burgdorferi, to integrin alphavbeta3. Proc Natl Acad Sci U S A (2003) 100(12):7301-6. doi:10.1073/pnas.1131117100

156. Talkington J, Nickell SP. Role of Fc gamma receptors in triggering host cell activation and cytokine release by Borrelia burgdorferi. Infect Immun (2001) 69(1):413-9. doi:10.1128/IAI.69.1.413-419.2001

157. Haupl T, Landgraf S, Netusil P, Biller N, Capiau C, Desmons P, et al. Activation of monocytes by three OspA vaccine candidates: lipoprotein OspA is a potent stimulator of monokines. FEMS Immunol Med Microbiol (1997) 19(1):15-23. doi:10.1016/S0928-8244(97)00046-1

158. Murthy PK, Dennis VA, Lasater BL, Philipp MT. Interleukin-10 modulates proinflammatory cytokines in the human monocytic cell line THP-1 stimulated with Borrelia burgdorferi lipoproteins. Infect Immun (2000) 68(12):6663-9. doi:10.1128/IAI.68.12.6663-6669.2000

159. Gautam A, Dixit S, Philipp MT, Singh SR, Morici LA, Kaushal D, et al. Interleukin-10 alters effector functions of multiple genes induced by Borrelia burgdorferi in macrophages to regulate Lyme disease inflammation. Infect Immun (2011) 79(12):4876-92. doi:10.1128/IAI.05451-11

160. Gautam A, Dixit S, Embers M, Gautam R, Philipp MT, Singh SR, et al. Different patterns of expression and of IL-10 modulation of inflammatory mediators from macrophages of Lyme disease-resistant and -susceptible mice. PLoS One (2012) 7(9):e43860. doi:10.1371/journal.pone.0043860

161. Ganapamo F, Dennis VA, Philipp MT. Differential acquired immune responsiveness to bacterial lipoproteins in Lyme disease-resistant and susceptible mouse strains. Eur J Immunol (2003) 33(7):1934-40. doi:10.1002/ eji.200323655

162. van Seventer GA, Shimizu Y, Horgan KJ, Shaw S. The LFA-1 ligand ICAM-1 provides an important costimulatory signal for $\mathrm{T}$ cell receptor-mediated activation of resting T cells. J Immunol (1990) 144(12):4579-86.

163. Bouis DA, Popova TG, Takashima A, Norgard MV. Dendritic cells phagocytose and are activated by Treponema pallidum. Infect Immun (2001) 69(1): 518-28. doi:10.1128/IAI.69.1.518-528.2001

164. Gondolf KB, Mihatsch M, Curschellas E, Dunn JJ, Batsford SR. Induction of experimental allergic arthritis with outer surface proteins of Borrelia burgdorferi. Arthritis Rheum (1994) 37(7):1070-7. doi:10.1002/art.1780370713

165. Guerrier G, D'Ortenzio E. The Jarisch-Herxheimerreaction in leptospirosis: a systematic review. PLoS One (2013) 8(3):e59266. doi:10.1371/journal.pone. 0059266

166. Belum GR, Belum VR, Chaitanya Arudra SK, Reddy BS. The JarischHerxheimer reaction: revisited. Travel Med Infect Dis (2013) 11(4):231-7. doi:10.1016/j.tmaid.2013.04.001

167. Kupper TS, Fuhlbrigge RC. Immune surveillance in the skin: mechanisms and clinical consequences. Nat Rev Immunol (2004) 4(3):211-22. doi:10.1038/ nri1310

168. Gergel EI, Furie MB. Populations of human T lymphocytes that traverse the vascular endothelium stimulated by Borrelia burgdorferi are enriched with cells that secrete gamma interferon. Infect Immun (2004) 72(3):1530-6. doi:10.1128/IAI.72.3.1530-1536.2004

169. Pivarcsi A, Bodai L, Rethi B, Kenderessy-Szabo A, Koreck A, Szell M, et al. Expression and function of toll-like receptors 2 and 4 in human keratinocytes. Int Immunol (2003) 15(6):721-30. doi:10.1093/intimm/dxg068

170. Takeuchi J, Watari E, Shinya E, Norose Y, Matsumoto M, Seya T, et al. Downregulation of toll-like receptor expression in monocyte-derived Langerhans cell-like cells: implications of low-responsiveness to bacterial components in the epidermal Langerhans cells. Biochem Biophys Res Commun (2003) 306(3):674-9. doi:10.1016/S0006-291X(03)01022-2

171. Cadavid D, Thomas DD, Crawley R, Barbour AG. Variability of a bacterial surface protein and disease expression in a possible mouse model of systemic Lyme borreliosis. J Exp Med (1994) 179(2):631-42. doi:10.1084/jem.179.2.631

172. Rawadi G, Garcia J, Lemercier B, Roman-Roman S. Signal transduction pathways involved in the activation of NF-kappa B, AP-1, and c-fos by Mycoplasma fermentans membrane lipoproteins in macrophages. J Immunol (1999) 162(4):2193-203.

173. Zhang H, Peterson JW, Niesel DW, Klimpel GR. Bacterial lipoprotein and lipopolysaccharide act synergistically to induce lethal shock and proinflammatory cytokine production. J Immunol (1997) 159(10):4868-78. 
174. Blanco DR, Reimann K, Skare J, Champion CI, Foley D, Exner MM, et al. Isolation of the outer membranes from Treponema pallidum and Treponema vincentii. J Bacteriol (1994) 176(19):6088-99.

175. Radolf JD, Robinson EJ, Bourell KW, Akins DR, Porcella SF, Weigel LM, et al. Characterization of outer membranes isolated from Treponema pallidum, the syphilis spirochete. Infect Immun (1995) 63(11):4244-52.

176. Radolf JD. Treponema pallidum and the quest for outer membrane proteins. Mol Microbiol (1995) 16(6):1067-73. doi:10.1111/j.1365-2958.1995.tb02332.x

177. Cameron CE, Castro C, Lukehart SA, Van Voorhis WC. Function and protective capacity of Treponema pallidum subsp. pallidum glycerophosphodiester phosphodiesterase. Infect Immun (1998) 66(12):5763-70.

178. Miller DP, McDowell JV, Bell JK, Marconi RT. Crystallization of the factor H-binding protein, FhbB, from the periopathogen Treponema denticola. Acta Crystallogr Sect F Struct Biol Cryst Commun (2011) 67(Pt 6):678-81. doi:10.1107/S1744309111011298

179. Miller DP, Bell JK, McDowell JV, Conrad DH, Burgner JW, Heroux A, et al. Structure of factor H-binding protein B (FhbB) of the periopathogen, Treponema denticola: insights into progression of periodontal disease. J Biol Chem (2012) 287(16):12715-22. doi:10.1074/jbc.M112.339721

180. Miller DP, McDowell JV, Rhodes DV, Allard A, Caimano M, Bell JK, et al. Sequence divergence in the Treponema denticola FhbB protein and its impact on factor H binding. Mol Oral Microbiol (2013) 28(4):316-30. doi:10.1111/ omi.12027

181. McDowell JV, Lankford J, Stamm L, Sadlon T, Gordon DL, Marconi RT Demonstration of factor $\mathrm{H}$-like protein 1 binding to Treponema denticola, a pathogen associated with periodontal disease in humans. Infect Immun (2005) 73(11):7126-32. doi:10.1128/IAI.73.11.7126-7132.2005

182. McDowell JV, Frederick J, Stamm L, Marconi RT. Identification of the gene encoding the FhbB protein of Treponema denticola, a highly unique factor H-like protein 1 binding protein. Infect Immun (2007) 75(2):1050-4. doi:10.1128/IAI.01458-06

183. McDowell JV, Huang B, Fenno JC, Marconi RT. Analysis of a unique interaction between the complement regulatory protein factor $\mathrm{H}$ and the periodontal pathogen Treponema denticola. Infect Immun (2009) 77(4):1417-25. doi:10.1128/IAI.01544-08

184. McDowell JV, Frederick J, Miller DP, Goetting-Minesky MP, Goodman H, Fenno JC, et al. Identification of the primary mechanism of complement evasion by the periodontal pathogen, Treponema denticola. Mol Oral Microbiol (2011) 26(2):140-9. doi:10.1111/j.2041-1014.2010.00598.x

185. Rosen G, Sela MN, Naor R, Halabi A, Barak V, Shapira L. Activation of murine macrophages by lipoprotein and lipooligosaccharide of Treponema denticola. Infect Immun (1999) 67(3):1180-6.

186. Sela MN, Bolotin A, Naor R, Weinberg A, Rosen G. Lipoproteins of Treponema denticola: their effect on human polymorphonuclear neutrophils. J Periodontal Res (1997) 32(5):455-66. doi:10.1111/j.1600-0765.1997.tb00558.x

187. Veith PD, Dashper SG, O’Brien-Simpson NM, Paolini RA, Orth R, Walsh KA, et al. Major proteins and antigens of Treponema denticola. Biochim Biophys Acta (2009) 1794(10):1421-32. doi:10.1016/j.bbapap.2009.06.001

188. Ishihara K. Virulence factors of Treponema denticola. Periodontol 2000 (2010) 54(1):117-35. doi:10.1111/j.1600-0757.2009.00345.x

189. Li X, Strle K, Wang P, Acosta DI, McHugh GA, Sikand N, et al. Tick-specific borrelial antigens appear to be upregulated in American but not European patients with Lyme arthritis, a late manifestation of Lyme borreliosis. J Infect Dis (2013) 208(6):934-41. doi:10.1093/infdis/jit269

190. Strle K, Shin JJ, Glickstein LJ, Steere AC. Association of a toll-like receptor 1 polymorphism with heightened Th1 inflammatory responses and antibioticrefractory Lyme arthritis. Arthritis Rheum (2012) 64(5):1497-507. doi:10.1002/ art. 34383

191. Steere AC, Klitz W, Drouin EE, Falk BA, Kwok WW, Nepom GT, et al. Antibiotic-refractory Lyme arthritis is associated with HLA-DR molecules that bind a Borrelia burgdorferi peptide. J Exp Med (2006) 203(4):961-71. doi:10.1084/jem.20052471

192. Bankhead T, Chaconas G. The role of VlsE antigenic variation in the Lyme disease spirochete: persistence through a mechanism that differs from other pathogens. Mol Microbiol (2007) 65(6):1547-58. doi:10.1111/j.1365-2958. 2007.05895.x

193. Philipp MT, Bowers LC, Fawcett PT, Jacobs MB, Liang FT, Marques AR, et al. Antibody response to IR6, a conserved immunodominant region of the
VlsE lipoprotein, wanes rapidly after antibiotic treatment of Borrelia burgdorferi infection in experimental animals and in humans. J Infect Dis (2001) 184(7):870-8. doi:10.1086/323392

194. de Silva AM, Zeidner NS, Zhang Y, Dolan MC, Piesman J, Fikrig E. Influence of outer surface protein A antibody on Borrelia burgdorferi within feeding ticks. Infect Immun (1999) 67(1):30-5.

195. Erdile LF, Brandt MA, Warakomski DJ, Westrack GJ, Sadziene A, Barbour AG, et al. Role of attached lipid in immunogenicity of Borrelia burgdorferi OspA. Infect Immun (1993) 61(1):81-90.

196. Sears JE, Fikrig E, Nakagawa TY, Deponte K, Marcantonio N, Kantor FS, et al. Molecular mapping of Osp-A mediated immunity against Borrelia burgdorferi, the agent of Lyme disease. J Immunol (1991) 147(6):1995-2000.

197. Johnson BJ, Sviat SL, Happ CM, Dunn JJ, Frantz JC, Mayer LW, et al. Incomplete protection of hamsters vaccinated with unlipidated OspA from Borrelia burgdorferi infection is associated with low levels of antibody to an epitope defined by mAb LA-2. Vaccine (1995) 13(12):1086-94. doi:10.1016/0264410X(95)00035-Y

198. Hanson MS, Cassatt DR, Guo BP, Patel NK, McCarthy MP, Dorward DW, et al. Active and passive immunity against Borrelia burgdorferi decorin binding protein A (DbpA) protects against infection. Infect Immun (1998) 66(5):2143-53.

199. Zuckert WR. A call to order at the spirochaetal host-pathogen interface. Mol Microbiol (2013) 89(2):207-11. doi:10.1111/mmi. 12286

200. Norman MU, Moriarty TJ, Dresser AR, Millen B, Kubes P, Chaconas G. Molecular mechanisms involved in vascular interactions of the Lyme disease pathogen in a living host. PLoS Pathog (2008) 4(10):e1000169. doi:10.1371/journal.ppat. 1000169

201. Yang X, Qin J, Promnares K, Kariu T, Anderson JF, Pal U. Novel microbial virulence factor triggers murine lyme arthritis. J Infect Dis (2013) 207(6):907-18. doi:10.1093/infdis/jis930

202. Vidal V, Scragg IG, Cutler SJ, Rockett KA, Fekade D, Warrell DA, et al. Variable major lipoprotein is a principal TNF-inducing factor of louse-borne relapsing fever. Nat Med (1998) 4(12):1416-20. doi:10.1038/4007

203. Rossmann E, Kraiczy P, Herzberger P, Skerka C, Kirschfink M, Simon MM, et al. Dual binding specificity of a Borrelia hermsii-associated complement regulator-acquiring surface protein for factor $\mathrm{H}$ and plasminogen discloses a putative virulence factor of relapsing fever spirochetes. J Immunol (2007) 178(11):7292-301. doi:10.4049/jimmunol.178.11.7292

204. Grosskinsky S, Schott M, Brenner C, Cutler SJ, Kraiczy P, Zipfel PF, et al. Borrelia recurrentis employs a novel multifunctional surface protein with anticomplement, anti-opsonic and invasive potential to escape innate immunity. PLoS One (2009) 4(3):e4858. doi:10.1371/journal.pone.0004858

205. Hovis KM, Jones JP, Sadlon T, Raval G, Gordon DL, Marconi RT. Molecular analyses of the interaction of Borrelia hermsii FhbA with the complement regulatory proteins factor $\mathrm{H}$ and factor H-like protein 1. Infect Immun (2006) 74(4):2007-14. doi:10.1128/IAI.74.4.2007-2014.2006

206. Hovis KM, McDowell JV, Griffin L, Marconi RT. Identification and characterization of a linear-plasmid-encoded factor H-binding protein (FhbA) of the relapsing fever spirochete Borrelia hermsii. J Bacteriol (2004) 186(9):2612-8. doi:10.1128/JB.186.9.2612-2618.2004

207. Grosskinsky S, Schott M, Brenner C, Cutler SJ, Simon MM, Wallich R. Human complement regulators $\mathrm{C} 4 \mathrm{~b}$-binding protein and $\mathrm{C} 1$ esterase inhibitor interact with a novel outer surface protein of Borrelia recurrentis. PLoS Negl Trop Dis (2010) 4(6):e698. doi:10.1371/journal.pntd.0000698

208. Werts C, Tapping RI, Mathison JC, Chuang TH, Kravchenko V, Saint G I, et al. Leptospiral lipopolysaccharide activates cells through a TLR2-dependent mechanism. Nat Immunol (2001) 2(4):346-52. doi:10.1038/86354

209. Haake DA, Mazel MK, McCoy AM, Milward F, Chao G, Matsunaga J, et al. Leptospiral outer membrane proteins OmpL1 and LipL41 exhibit synergistic immunoprotection. Infect Immun (1999) 67(12):6572-82.

210. Verma A, Artiushin S, Matsunaga J, Haake DA, Timoney JF. LruA and LruB, novel lipoproteins of pathogenic Leptospira interrogans associated with equine recurrent uveitis. Infect Immun (2005) 73(11):7259-66. doi:10.1128/IAI.73.11. 7259-7266.2005

211. Verma A, Rathinam SR, Priya CG, Muthukkaruppan VR, Stevenson B, Timoney JF. LruA and LruB antibodies in sera of humans with leptospiral uveitis. Clin Vaccine Immunol (2008) 15(6):1019-23. doi:10.1128/CVI.00203-07

212. Verma A, Kumar P, Babb K, Timoney JF, Stevenson B. Cross-reactivity of antibodies against leptospiral recurrent uveitis-associated proteins A and B 
(LruA and LruB) with eye proteins. PLoS Negl Trop Dis (2010) 4(8):e778. doi:10.1371/journal.pntd.0000778

213. Zhang K, Murray GL, Seemann T, Srikram A, Bartpho T, Sermswan RW, et al. Leptospiral LruA is required for virulence and modulates an interaction with mammalian apolipoprotein AI. Infect Immun (2013) 81(10):3872-9. doi:10.1128/IAI.01195-12

214. Cinco M, Domenis R, Perticarari S, Presani G, Marangoni A, Blasi E. Interaction of leptospires with murine microglial cells. New Microbiol (2006) 29(3):193-9.

215. Blasi E, Ardizzoni A, Colombari B, Neglia R, Baschieri C, Peppoloni S, et al. NF$\mathrm{kB}$ activation and $\mathrm{p} 38$ phosphorylation in microglial cells infected with Leptospira or exposed to partially purified leptospiral lipoproteins. Microb Pathog (2007) 42(2-3):80-7. doi:10.1016/j.micpath.2006.11.002

216. Klimpel GR, Matthias MA, Vinetz JM. Leptospira interrogans activation of human peripheral blood mononuclear cells: preferential expansion of TCR gamma delta $+\mathrm{T}$ cells vs TCR alpha beta+ T cells. J Immunol (2003) 171(3):1447-55. doi:10.4049/jimmunol.171.3.1447

217. Nally JE, Whitelegge JP, Bassilian S, Blanco DR, Lovett MA. Characterization of the outer membrane proteome of Leptospira interrogans expressed during acute lethal infection. Infect Immun (2007) 75(2):766-73. doi:10.1128/IAI.00741-06

218. Habarta A, Abreu PA, Olivera N, Hauk P, Cedola MT, Ferrer MF, et al. Increased immunogenicity to LipL32 of Leptospira interrogans when expressed as a fusion protein with the cholera toxin B subunit. Curr Microbiol (2011) 62(2):526-31. doi:10.1007/s00284-010-9739-6

219. Seixas FK, Fernandes CH, Hartwig DD, Conceicao FR, Aleixo JA, Dellagostin OA. Evaluation of different ways of presenting LipL32 to the immune system with the aim of developing a recombinant vaccine against leptospirosis. Can J Microbiol (2007) 53(4):472-9. doi:10.1139/w06-138

220. Silva EF, Medeiros MA, McBride AJ, Matsunaga J, Esteves GS, Ramos JG, et al. The terminal portion of leptospiral immunoglobulin-like protein LigA confers protective immunity against lethal infection in the hamster model of leptospirosis. Vaccine (2007) 25(33):6277-86. doi:10.1016/j.vaccine.2007.05. 053

221. Koizumi N, Watanabe H. Leptospiral immunoglobulin-like proteins elicit protective immunity. Vaccine (2004) 22(11-12):1545-52. doi:10.1016/j.vaccine. 2003.10.007

222. Cinco M. New insights into the pathogenicity of leptospires: evasion of host defences. New Microbiol (2010) 33(4):283-92.

223. La T, Phillips ND, Reichel MP, Hampson DJ. Protection of pigs from swine dysentery by vaccination with recombinant BmpB, a $29.7 \mathrm{kDa}$ outermembrane lipoprotein of Brachyspira hyodysenteriae. Vet Microbiol (2004) 102(1-2):97-109. doi:10.1016/j.vetmic.2004.06.004

Conflict of Interest Statement: The author declares that the research was conducted in the absence of any commercial or financial relationships that could be construed as a potential conflict of interest.

Received: 08 January 2014; accepted: 17 June 2014; published online: 30 June 2014. Citation: Kelesidis T (2014) The cross-talk between spirochetal lipoproteins and immunity. Front. Immunol. 5:310. doi: 10.3389/fimmu.2014.00310

This article was submitted to Microbial Immunology, a section of the journal Frontiers in Immunology.

Copyright $\odot 2014$ Kelesidis. This is an open-access article distributed under the terms of the Creative Commons Attribution License (CC BY). The use, distribution or reproduction in other forums is permitted, provided the original author(s) or licensor are credited and that the original publication in this journal is cited, in accordance with accepted academic practice. No use, distribution or reproduction is permitted which does not comply with these terms. 